\title{
LINGUISTIC AND CULTURAL BIOGRAPHY OF REGIONAL GEOGRAPHICAL OBJECTS AS A MEANS OF FORMING TOPONYMIC LITERACY OF STUDENTS
}

\author{
Flera Ya. Khabibullina ${ }^{1 *}$, Iraida G. Ivanova ${ }^{2}$, Nikolaj A. Kirillov ${ }^{3}$, and Konstantin G. \\ Matkov ${ }^{4}$ \\ ${ }^{1}$ Ass. Prof. Dr., Mari State University, Yoshkar-Ola, RUSSIA, khflora@yandex.ru \\ ${ }^{2}$ Ass. Prof. Dr., Mari State University, Yoshkar-Ola, RUSSIA, iraida44@yandex.ru \\ ${ }^{3}$ Prof. Dr., Chuvash State University, Cheboksary, RUSSIA, kna27zergut@mail.ru \\ ${ }^{4}$ Ass. Prof. Dr., Chuvash State University, Cheboksary, RUSSIA, matjkovkg@mail.ru \\ ${ }^{*}$ Corresponding author
}

\begin{abstract}
Knowledge of the territory of the region has been developing since the first days of cartography, in the XVIII century. Geography is the knowledge that is necessary to understand the landscape and geographical features of the place of residence, its transformation in the course of economic, historical and cultural development, as well as to prepare the region and the country for tomorrow. It is toponyms that act as living witnesses of the historical past and present of the region, expressed by means of language. The study of toponyms allows us to consider the meaning and origin of lexical units of this layer of the language, its evolution and functioning in the modern language. Deciphering toponyms makes it possible to restore the historical and cultural past of the region and the ethnos: toponyms perform the function of "accumulating memory" - historical, event, ideological, linguistic, fixing the history of the region. This has become especially relevant in recent decades, when many geographical objects on the territory of Russia and its subjects are being renamed, old names are being returned to them, which changes the cultural and geographical landscape in the toponymic system of national identity. Toponymy is the most important element of the national educational system. It serves as a means of stimulating and developing interest in the study of the past and present of one's region by searching for links between geographical conditions and their reflection in geographical names. Toponymists investigate, as a rule, the relationship between natural conditions and their reflection in geographical names in order to know all the components of toponymy. The use of regional toponymic material more fully, more clearly characterizes the geographical environment, acts as a means of forming the toponymic literacy of students. The purpose of the article is the formation of toponymic literacy of students on the basis of generalized linguistic and cultural biographies of regional geographical objects. The object of the research is linguistic and cultural biography as a set of lexical - semantic and structural grammatical means of representation of ideas about topoobjects objectified on the map and in the catalog of toponymic names.
\end{abstract}

The novelty of the study of the problem of the formation of toponymic literacy of students in the framework of this work consists in the integration of cycles of disciplines of natural science and humanities, while the previous concepts were based on the construction of cognitive activity of students in the study of disciplines of the natural geographical cycle. The structural and semantic aspect of language learning is necessary for the formation of language competence. It is supplemented by the cultural aspect, which forms cultural competence and stimulates the familiarization of students with cultural and nationally significant values of the region of residence. The toponymic fund of the region is one of the resources for the formation of toponymic 
literacy of students. It translates the national identity of linguistic facts describing geographical objects and their historical and cultural specifics. Toponymic literacy is a set of competencies that develops the student's ability to navigate the geographical, cultural and linguistic space of a locality and, based on value understanding, helps the student to enter the world of the surrounding community and the world of his native language and national culture. The article describes the role and possibilities of the catalog of linguistic and cultural biography of regional toponymic objects as a means of forming the toponymic literacy of students. The structure of the catalog of each geographical object includes its comprehensive description, consisting of the following characteristics: the type of toponym, the name in the national language and its pronunciation variants, the name variants (official and unofficial), the municipal area of the object location, the type of settlement (rural / urban settlement), the composition of the population, famous people, the infrastructure of the locality, sights, photographs of a geographical object, the type of geographical object, location, physical and geographical information, geographical coordinates, map, etymology of the name, history, legends, economic significance for the region and country, bibliographic sources. For more in-depth work with the catalog of geo objects, it is advisable to study regional toponymy in the process of extracurricular work. Toponymic material can be collected by the students themselves as a result of a survey of the local population or extracted from written sources. Geographical names are available for observation, systematization and classification, analysis, description, mapping. Under the guidance of a teacher, students can master the skills of linguistic analysis of toponyms, the study of their origin and the establishment of etymology. The analysis of toponyms will certainly require the involvement of such vocabulary groups as common names or appellatives, personal names of people (anthroponyms), nicknames and names of animals (zoonyms), names of celestial bodies (astronyms), names of tribes and peoples (ethnonyms), names of vegetation (phytonyms), names of organizations and institutions (ergonyms), etc., dialect vocabulary, historical events and facts, comparison of visual observations with the reflection of the toponymic situation on the map and atlas. For toponymic research on compiling and updating the catalog of linguistic and cultural biography of toponymic objects, archival materials, documentary, popular science and fiction, geographical maps, schemes and reference books of administrative divisions of different years, dictionaries and reference publications are involved. An important place is occupied by excursions and expeditions to the settlements of the region, visits to museums and libraries, art objects. The practical application of the results obtained in the study consists in the possibility of developing teaching aids and workshops on the methodology of teaching natural geography (natural history, geography, ecology, geography of the region) and linguistic disciplines (history of language, native language and literature, national culture, history and culture of the people), as well as in the development and conduct of new special courses and special seminars for high school students.

Keywords: geography, integrative approach, linguistic and cultural biography, catalog, regional toponymy, geographical object, toponymic literacy, students.

\section{INTRODUCTION}

The relevance of the topic is due to the need to develop the student's ability to navigate the geographical, cultural and linguistic space of the region and on the basis of his value understanding to enter the world around him and into the world of his native language and national culture. The toponymic fund of the region translates the national identity of linguistic facts describing geographical objects and their historical and cultural specifics. It is toponyms that act as living witnesses of the historical past and present of the region, expressed by means of language. Their research allows us to consider the meaning and origin of lexical units of this layer of language, its evolution and functioning in the modern language. Toponyms perform the function of memorization of topoobjects and accumulation of historical, event, ideological, linguistic memory of the territory. This has become especially relevant in recent decades, when many geographical objects on the territory of Russia and its subjects are being renamed, old names are being returned to them, which changes the cultural and geographical landscape in the toponymic system of national identity.

Toponymy is the most important element of the national educational system. The use of regional toponymic material characterizes the geographical environment more fully and clearly, acts as a means of forming the toponymic literacy of students. The purpose of the study is to present the technology of formation of toponymic literacy of students, which is aimed at developing the ability of students to navigate in the geographical, cultural and linguistic space of regional toponymic objects. The article describes the models of 
the linguistic-geographical passport, linguistic-cultural portrait and linguistic-cultural biography of a toponym as a means of forming the toponymic literacy of students in the educational process. The scientific novelty of the work lies in the integration of geographical and linguistic directions in the study of geographical objects and their names by students during the implementation of design and research activities, while previous concepts in the formation of toponymic literacy were mainly based on the construction of cognitive activity based on the disciplines of the natural geographical cycle. The objectives of this study are to: clarify the role and possibilities of a linguistic geographical passport, a linguistic and cultural portrait and a linguistic and cultural biography as key means of developing toponymic literacy of students; to build a sequence of actions for their application in the design and research activities of students; to present samples-models of their compilation.

\section{METHODOLOGY AND METHODS}

In the course of the research, the following methods were used: literature analysis, synthesis, generalization, systematization, modeling. The work is based on the names of geo objects of the Republic of Mari El (RME) describing the toponymic zones of the RME (Habibullina, Ivanova, 2020, pp. 259-285), including microtoponyms, as part of the regional onomastic space (Habibullina, Ivanova, 2020, pp. 288-295).

\section{LITERATURE REVIEW}

The theoretical basis is research on the formation of toponymic literacy of students in the context of the use of linguistic and local history material in the study of the native language (I.I. Zhilenkova, N.V. Korotkova, G.F. Kovalev, S.I. Lvova, L.K. Lyzhova, L.I. Lyapina, T.V. Mayorova, V.A. Magin, N.T. Uzdenova, etc.), the use of various types of toponymic vocabulary in Russian lessons (M.V. Vostrikova, V.V. Demicheva, G.A. Druchinina, O.I. Eremenko, L.P. Efanova, L.V. Kozlova, L.M. Kurganskaya, G.A. Kulyupina, N.A. Melikova, E.O. Orlova S.A. Popova, etc.). These works focus on the linguo-regional aspect of linguistics associated with the concepts of "location" and "topos". Toponymic literacy was studied within the framework of the problems of increasing the cognitive activity of students through the use of the regional toponymic fund (M.P. Ivanov). The geo-names of the region were considered from the point of view of linguistics (composition of names), history (identification of the boundaries of the ancient settlement of peoples), typification of toponymic material (illustration on maps by groups of toponyms). The regional toponymicon was portrayed from the position of the linguoecological approach (llyin, 2018, pp.99-107). It should be noted that portraiture, as a branch of interdisciplinary knowledge, was used initially in the field of politics when describing personalities, while attention was paid to the linguistic component of the portrait (Khabibullina F.Ya., Ivanova I.G., Trapeznikova G.A., 2018, pp.543-555). A toponym card has been developed as one of the main structural elements of any toponymic database that characterizes toponyms of different categories as fully and comprehensively as possible (Gordova, 2014, pp.58-61). The issues of formation of toponymic competence of future geography teachers in the theoretical aspect were developed by V.E. Steinberg (2013), R. M. Asadullin, L.I. Vasiliev, V.G. Ivanov (2008) and others E.A. Gonchar, as a tool for the issue under study, offers logical and semantic modeling, including coordinates corresponding to the components of educational technology and the stages of its design (Gonchar, 2014, pp.93-98).

\section{RESULTS AND DISCUSSION}

Toponymic literacy is one of the content areas of modern education. This is a set of competencies that develops the student's ability to navigate in the geographical, cultural and linguistic space of the national toposystem, the study of which forms a system of skills and abilities of lexico-semantic, structuralgrammatical and etymological analysis, knowledge about local culture and history extracted from linguistic units with regional-cultural connotation. The formation of toponymic literacy aims to generalize and systematize students' knowledge about the structure and features of the functioning of the national toponymic system, expand linguistic horizons and increase the cultural competence of participants in the educational process. Components of toponymic literacy: 1) motivational - stable motivation to study geographical objects and their names, due to the interest in replenishing toponymic knowledge and developing skills in situations of their frequent use; 2) meaningful - a unified set of knowledge, skills and abilities to work with the reference geographical nomenclature (list of toponyms), the main components of which are "Toponym as a lexical unit in Russian and national languages", "Geographical location of a topoobject", "Socio-cultural and historical reference", "Linguistic and cultural image and semantic correlations"; 3) practice-oriented - is associated with the acquisition by students of the relevant knowledge, skills and abilities in the study of the language of geographical names, built according to the algorithm: "fill out a linguistic and geographical passport" $\rightarrow$ "make a linguistic and cultural portrait" $\rightarrow$ "write a linguistic and cultural biography". The collective product of each stage of the project and research activity of students 
studying the regional toponymicon are: "card file of linguistic and geographical passports of topoobjects" $\rightarrow$ "linguistic and regional dictionary of regional toponyms" $\rightarrow$ "catalog of linguistic and cultural biographies of georealia". Thus, toponymic literacy reflects a wide range of competencies of students related to the characteristics of geographical objects of the region: linguistic, general cultural, historical, socio-cultural, personal-value, etc.

Geographical names are available for observation, systematization and classification, analysis, description, mapping. Information about topoobjects can be collected by students themselves as a result of a survey of the local population or extracted from written sources (dictionaries and reference publications, programs, archival materials, documentary, popular science and fiction, geographical maps, diagrams and reference books of administrative divisions, etc.). Under the guidance of a teacher, students can master the skills of linguistic analysis of toponyms, the study of their origin and the establishment of etymology. The analysis of toponyms will require the involvement of such vocabulary groups as common names or appellatives, personal names of people (anthroponyms), nicknames and names of animals (zoonyms), names of celestial bodies (astronyms), names of tribes and peoples (ethnonyms), names of vegetation (phytonyms), names of organizations and institutions (ergonyms), etc., historical events and facts, comparison of visual observations with the reflection of the toponymic situation on the map and atlas. An important place is occupied by excursions and expeditions to the settlements of the region, visits to museums and libraries, art objects.

Work with topoobjects and their names is an independent and important direction of the educational process, which meets the requirements of the formation of toponymic literacy, including:

Goals: 1) Personal: awareness of one's civic identity as a citizen of Russia; fostering love and respect for one's native region and the surrounding world. 2) Subject (geography, native language and literature, history of the culture of the people, Russian and foreign languages): familiarization with the concepts of "onym", "toponym" and "toponymy", classes of geographical names, types of toponyms by the nature of nominations, deepening and expanding knowledge about the functioning of toponyms, etc. 3) Meta-subject: the use of reference publications, Internet resources, lexicographic sources (toponymic dictionaries), geographical maps in order to find the necessary information; the ability to correctly design models of the presentation of a geographical object in the form of a linguistic and geographical passport, linguistic and cultural portrait and linguistic biography, to build messages orally, to work in a team, to cooperate in a group in the formation of a creative product - a card index, dictionary and catalog of toponyms, etc.

Tasks: 1) To form an idea of the concepts of "onym", "toponym" and "toponymy" based on lexicographic sources. 2) Develop the ability to distinguish three aspects in the description of a geo object: linguistic, historical-cultural and socio-cultural. The linguistic aspect implies familiarity with linguistic phenomena (toponymic vocabulary, nomenclature vocabulary, appellatives, borrowings, etc.), the main classes of toponyms: oikonyms (names of settlements: cities (urbanonyms), villages, villages, settlements (komonyms)), oronyms (names of landforms: mountains, peaks, plains, depressions, caves, etc.), hydronyms (names of all water bodies: rivers, streams, ponds, lakes sources, wells, seas, oceans, etc.), dreamonyms (names of forests, groves, parks and their parts), dromonyms (names of transport routes), urbanonyms (names of any inner-city objects), buronyms (names of any significant territories, regions, regions), microtoponyms (names of small objects), disappeared toponyms. To familiarize with the methodology of linguistic analysis of toponyms (lexical-semantic, structural-grammatical, etymological). 3) To update knowledge about the historical, personological, cultural, socio-cultural contexts of geographical objects of the region. The historical and cultural aspect consists in acquaintance with history and linguistic culture (historical onomastics, memoratives, historicisms, ideologisms, the language of local historical documents, phraseology, the language of folklore, etc.). The socio-cultural aspect is realized through the appeal to the language of regional media, literary and artistic works, to the special vocabulary of professions, the organization of city excursions and expeditions, visits to museums and libraries, etc.). 4) To ensure that students are introduced to cultural and nationally significant values, students' understanding of national identity, interpretation of toponyms as linguistic facts specific to a particular region of Russia. 5) To teach the identification, classification, generalization and design of topoobjects in the form of a creative product.

The main teaching methods are descriptive and comparative based on direct observation, a method of collecting and systematizing geographical names, their classification, interpretation, proof, generalization, quantitative analysis; private scientific linguistic technologies - techniques of linguistic and cultural commentary, contextual, lexical-semantic, structural-grammatical and etymological analysis.

Key learning tools:

The linguogeographic passport implies selected and characterized by the property of completeness 
information about the topoobject and the toponym designated by the word, including the thematic connections of the keyword and its compatibility. The structure of the passport of a topoobject includes the following information: the name of the object, the full name in Russian and national languages, the type of geo object, its profile, area, level of significance, year of foundation, location in the structure of administrative-territorial division, district, municipality, main attractions, type of toponym, toponym structure, lexico-semantic characteristics, etymology and some others. The set of linguistic and geographical passports is presented in the card file.

The linguistic and cultural portrait is used in the study of artifacts, in identifying the uniqueness of a particular topoobject of the region. It reflects the totality of its characteristics characteristic of the portrayed object as a complex integrity, within which the dominant and peripheral

features of the studied topoobject are prescribed. In relation to the analysis of the toponymicon, portraiture makes it possible to study this phenomenon by familiarizing students with toponyms as units of language reflecting regional regional realities, etc.

Linguocultural biography as a complex of lexico - semantic and structural - the grammatical means of representation of ideas about topoobjects objectified in the catalog of toponymic names includes the following characteristics in its structure: the type of toponym, the name in the national language and its pronunciation variants, the name variants (official and unofficial), the municipal area of the object location, the type of settlement (rural / urban settlement), the composition of the population, famous people, the infrastructure of the settlement, attractions, photographs of the geographical object, the type of geographical object, location, physical and geographical information, geographical coordinates, map, etymology of the name, history, legends, economic significance for the region and the country, bibliographic sources.

Stages. Work with toponymic material is a step-by-step, consistently complicated set of actions and operations aimed and focused on the formation of toponymic literacy through the compilation of a linguistic and geographical passport $\rightarrow$ linguistic and cultural portrait $\rightarrow$ linguistic and cultural biography of a geographical object.

The criteria for evaluating the effectiveness of the technology for the formation of toponymic literacy based on regional toponymic material are: the level of interest in the disciplines of natural-geographical and humanitarian cycles, the quality of assimilation of geographical and linguocultural knowledge about topoobjects, the activity of students in the process of educational and extracurricular educational activities for the assimilation of geographical and linguistic knowledge, skills and abilities when using regional toponymic material, the products of practical work with topomaterial: a card file based on linguistic and geographical passports of topographical objects (stage 1), a dictionary of regional toponyms based on linguistic and cultural portraits (stage 2), a catalog of regional toponyms, which reflects the linguistic and cultural biographies of old and new names of toponymic objects (stage 3).

Models are a valuable tool that allows combining natural-geographical and humanitarian cycles in the study of regional toponyms.

\subsection{Linguistic and Geographical Passport of a Geo Object}

Research work. "Secrets of National geography".

Task. Uncover the secrets of the following topobjects of the RME and make up their linguistic and geographical passport: 1 . The lake is known from the film "53 meters", which was filmed in September 2004. The picture was among the best hits of the Yushut festival (Answer: lake Tair). 2. A protected area, on the territory of which the following well-known recreations are located: Yalchik, Kichier, Maple Mountain, Mushan-Er, Glukhoe (Answer: Mari Chodra). 5. The ancient daruga, which for centuries connected Kazan and the Vyatka Region, passed through the territory of Mari El through the settlements of Shorunzha, llet, Paranga, Kosolapovo, Mari Sola, Sernur, Novy Toryal, Mari Turek (Answer: Alatsky tract).

Installation: Knowledge of the territory of the region has been developing since the advent of cartography, in the XVIII century. Geography is the knowledge that is necessary to understand our republic, as well as to prepare it for tomorrow. Uncover the secrets of the Republic of Mari El, shaped by time. Make a linguistic and cultural passport of the geo-object.

Question: The object has scientific and educational significance. The Siberian cedar stand, planted on the territory of Mari El in 1910, is subject to protection. Name the object and make up its linguistic and geographical passport (Answer: Cedar grove).

Example: 
Proceedings of INTCESS 2022- 9th International Conference on Education \& Education of Social Sciences 17-18 January 2022- Online Conference

\begin{tabular}{|c|c|}
\hline PARAMETER & VALUE \\
\hline Name of the object & $\begin{array}{l}\text { Territorial zone with a special use regime of the territory of } \\
\text { the nature monument of republican significance "Cedar } \\
\text { Grove" }\end{array}$ \\
\hline Full name & $\begin{array}{l}\text { Nature monument of republican significance of the } \\
\text { Republic of Mari El "Cedar Grove (1910)". }\end{array}$ \\
\hline National name & mar. Kedr rosha \\
\hline Type of geo object & $\begin{array}{l}\text { The territory of a specially protected natural object } \\
\text { (protected area) }\end{array}$ \\
\hline Protected area profile & Biological monument of nature \\
\hline Area & $0.3 \mathrm{ha}$ \\
\hline Value level & Republican \\
\hline Year of creation of the protected area & 15.07.1987 \\
\hline $\begin{array}{l}\text { Location of protected areas in the } \\
\text { structure of administrative-territorial } \\
\text { division }\end{array}$ & Volga Federal District, Republic of Mari El \\
\hline District & Gornomariyskiy \\
\hline Municipality & Paygusovskoye \\
\hline Main sights & Rural settlement \\
\hline Type of toponym & Forest cultures of cedar (Siberian pine) \\
\hline Toponym structure & Dreamonym \\
\hline Lexical and semantic characteristics & $\begin{array}{l}\text { The toponym is composite, two-component, with an agreed } \\
\text { definition: model = Adj }+\mathrm{N} \text {. A toponym with a component } \\
\text { denoting flora is a phytonym. }\end{array}$ \\
\hline Etymology & $\begin{array}{l}\text { The word is borrowed from the Old Slavic language, which } \\
\text { goes back to the Greek kedros: cf. cedar < Greek. kedros } \\
\text { "pine, cedar". The Mar. rocha component is the result of } \\
\text { phonetic adaptation of the Russian grove. }\end{array}$ \\
\hline
\end{tabular}

\subsection{Linguistic and Cultural Portrait}

Project: "Lakes tourist route in the Republic of Mari El"

Task: Make a linguistic and cultural portrait of the following lake of Mari El: Kuzh-Er, Konan-Er, Morskoj glaz, Tabashinskoe, Yal'chik. Organization of excursions for tourist Yalchik.

Setting: in Mari El, there are more than seven lakes and a river. The New Year's purity of the waters and the pond are famous for the unsurpassed Lake. Many of the epics of lakes of various kinds are covered with legends and brittle.

Question: Imagine the structure of the linguistic and cultural portrait of the lake. Elanier.

Example: 
Toponym form: hydronym.

Hydronym type: limnonim.

Variants of the name: Elan-Er.

Official name in Russian: Lake Elan'er.

Transfer of the name in the national language: Elanier.

Name in the national language Pronunciation: [jelan'jer]

Subjects of the Federation: Republic of Mari El. District: Koramas rural settlement of Volzhsky district.

Geo Object Location: the lake is located $4 \mathrm{~km}$ from the nearest settlement - the village of Chodyrayal, in the south-eastern part of the RME.

Location on the map: http://12. maphost.ru/map.php?map=main\&id=6314058

Topoobject description: Lake. The Elanier has an oval oblong shape, 800-900 meters long, 200-250 meters wide. The Lake consists of two parts: Big Elanier and Small Elanier, which previously formed a single lake. The lake is clean and transparent, the maximum depth is 4-5 meters. There is a system of sinkholes at the bottom of the lake and cave. The spring has a hydro and underground power supply.

Toponymization structure: The name is complex, consisting of two words: Elan + er, where Elan is a "snake", cf.: tat. elan "snake" + mar. ep "lake", that is "Snake Lake".

Etymology of the name: the Tatar language is borrowed from the Turkic name of the components and the Mari language of the lake. In the Volzhsky district of the RME and in the Republic of Tatarstan, the lake is located on the border of Elan'er, that is, native speakers of the Tatar language are in the contact zone. For centuries, Mari and Tatars have lived in border areas. Limnonym is of non-Marian origin, cf.: Mar. kishke "snake". The word elan is found in many Turkic languages, for example, Tatar, Bashkir, Turkish, Chuvash, etc. So, in the Bashkir language of worms is the name of Jylan, which was part of the Nizhnebelskoy Bashkir group, denoting the ancient Turkic descendants of one of the islands. Many ancient peoples have ethnonym snakes for the veneration of the totem. Figuratively, the meaning of the word "snake" is an invective of the name of an evil, insidious person.

Geo Object Photos: https://www.12rm.ru/ozera-bolshoj-i-malyj-elan-er/

Linguistic and cultural information. Topo object legends:

1. According to the legend the lake Elan-Er was located near Mount Elan Kuryk and was surrounded by a dense forest. A place rich in fish and game and, rushing out of the pits, attracted to wander. As the legend says, the king of the mountain, there was a huge Snake in the caves of Elan Kuryk. Geologists discovered a chain of Sotnur lakes and Klenovaya Gora lake, connected by a huge underwater river, located almost parallel to the river llet. The image of the Serpent is found in both Tatar and Mari legends. So, on the territory of Tatarstan near the village of Aybash there is a lake Kara-Kul, where there is a similar legend about the mythical snake-monster living in the lake, which in the Tatar language is called Sugeze "water bull". Thus, similar karst lakes, possibly connected by an underground river, have similar legends. In Mari it is huge and there are frequent legends and mentions of the mythical yomakys Tatar Snakes. So, in the Mari legend about the "Prince of the horns" there is an episode where the main character and his beloved, deliver the people from the ruler's decision, I do not receive the help of an oak tree, with which a snake is fighting. Samuel V. "Magic basketball court" Dragon hunters defeat the three-headed swamp Yuanai inhabiting Turni (cf. Komi Gundyr).

2. The snake of the huge Dragon epic eventful Mari narrates the canvas of the "God of Jupu or tree", on which the Knight no longer relies on heroic plots, entering into a confrontation with man-eating snakes. Folklore is the first Mari attempt to systematize the text of the poem, the stories were based on A.A. Apkalikov (1918-1999), a native of the village Yandyganovo of district Mishka (Bashkir ASSR), Mari and based on the material of historical myths on legends, as well as information printed in the rya and the song of already folk contained research, epic creativity including other monuments of Finno-Ugric ethnic groups.

3. The cult of the snake has survived among the local population, for example, in the village of Chedrayal. Almost all the indigenous inhabitants of nearby villages have on their hands the remains of the fangs of ancient snakes $4-4.5 \mathrm{~cm}$ long, a 4-meter-long shed skin of a swamp viper. New town and snake skulls festive ceremonial local decorated with Chien, snakes totem embroidery, bull, etc. 
4. In the legend "Luodis of Heaven and daughters" (the great daughter in the Mari pagan religion of the supreme God), it is narrated that the one that is big-the Snake turns into God.

\subsection{Linguistic and Cultural Biography}

Research project: "Toponymicon of my republic".

Task. Make a linguistic and cultural biography of one of the five following topoobjects of the RME: YoshkarOla, Ilet, Odo kurzhmo korno, vill. Shinsha, Boulevard Chavain, Tatar mill, factory "Mariets".

Setting: To make a linguocultural biography of a toponym.

Question: Draw up a linguistic and cultural biography of the village of Pektubaevo.

Example:

Type of toponym: oikonym. Type of oikonym: komonym.

Official name in Russian: Pektubaevo. Transfer of the name in the national language: Kakshanmuchash (lugovomar.). Pronunciation of the name in the national language: [kakshanmuchash].

Variants of the name: Kakshan Muchash, Hristorozhdestvenskoe.

Subject of the Federation: Republic of Mari El. Municipal district and settlement: Novotoryalsky district, rural settlement of Pektubaevskoye.

The population of oikonim: 1314 people.

Object coordinates: latitude: $57^{\circ} 01^{\prime} 40^{\prime \prime}$ s.w.; longitude: $48^{\circ} 23^{\prime} 07^{\prime \prime}$ w.d.

The location of the object: the village of Pektubaevo is located on the right bank of the Nurma River, $24 \mathrm{~km}$ from the district center, the village of Novy Toryal, in the northeastern part of the RME.

Location on the map: https://kartarf.ru/poselki/pektubaevo

Infrastructure of the settlement: The highway of regional significance 88K-015 Orshanka - Pektubaevo Novy Toryal passes through the village of Pektubaevo. The village is the terminus of the local highway $88 \mathrm{~N}$ 13001 Alekseevsky - Sredny Kadam - Pektubaevo, which connects it with the major highway 88K-001 Yoshkar-Ola- Urzhum. In the village there are Pektubaevskaya secondary school, kindergarten No. 5 "Smile", a paramedic-obstetric station, etc.

The structure of the toponymy: hydronymic oikonym, consists of two words: Kakshan - hydronym + muchash "end, source", that is, the source of the Kakshan river. The village is located at the source of the Malaya Kokshaga River.

Etymology of the name: The official variant is anthroponymous, cf.: Pektubai is a male personal name of the Mari people, indicates the first settler, consists of others Turkic beck "strong"+tuba " race"+-i - suffix (S.Ya. Chernykh, 1978, 1995); beck "ruler"+tuu "to be born"+ buy "rich", that is, "A rich ruler was born" (O.P. Vorontsova, I.S. Galkin, 2002).

Famous natives: Matveev Gennady Konstantinovich (1908-1996) Soviet scientist, Doctor of Law (1951), Professor (1953). He researched the problems of civil, family and international private law. Author of more than 100 scientific papers, including monographs. Graduated from the Kazan Law Institute, worked in the Kazan State University and Kiev State University.

Attractions: Pektubaevsky rural House of Culture, Pektubaevskaya rural library (1870), which is considered the oldest in the district. The Church of the Nativity of Christ (Nativity of Christ) - the first church in the village (wooden and single-altar) - was built in 1734.

Photos of the geographical object: https://rodnaya-vyatka.ru/places/74130

History: In the village of Pektubaevo in the XVIII century there was a Yamskaya station, where there were from 7 to 10 horses. Its first holder was S. Ukhov. In the middle of the XIX century. there were 52 farms in the village, there were a station, a bread shop, a parish school, five shops. Bazaars were open on Sundays and holidays. The merchant U.D. Nekhoroshkov was considered a famous merchant, he owned a two-story building in the center of the village, which housed the post office until 1898. In 1924, the Pektubaevskaya hut-reading room was opened (the first head was A. Egoshin). In 1918, the committee of the poor was created, in 1924 - the first party cell (secretary - P.V. Bertnikov), in 1923 - the Komsomol cell, which organized circles for young people: political, agricultural, newspaper, self-education, drama, choral. In 1936, 
the decree of the Presidium of the MAO was issued on the closure of the church and the transfer of the temple to a club, library, radio center. During the first years of Soviet power, 250 houses were built in the village, the building of the district executive committee, a hospital, MTS, a machine and tractor park, a flax factory, a bakery, an industrial plant and a sewing workshop, a pottery workshop, the "Dawn" artel, a shoemaking workshop, workshops for sheepskin, tin, a wool churn. The newspaper "Stalin Korno" ("Stalin's Way") was published in the district center. The machine partnership "Pektubaevskoe" was founded in 1928. In 1930, the agricultural cartel "Svobodny Put" was established. A nursery-garden for 140 places, a district hospital, a secondary school, a new administrative building of the village Council with a public order point were put into operation and put into operation.

Linguistic and cultural information. Legends about the topoobject: According to legend, at the beginning of the XVI century, the first settlers arrived on the territory of modern Pektubaevo and nearby lands. These were seven owners by the name of Pektubaev and Sokolov from the same Mari tribe, In order to clear the place for sowing, they began to cut down and burn the forest. It was these first settlers who created two villages on the Nurma River: the now-defunct Mari villages of Verkhne Yanaevo and Nizhne Yanaevo, which later became part of the village of Pektubaevo.

\section{CONCLUSIONS.}

The regional toponymic material gives a vivid idea of the peculiarities of the region: physical-geographical, demographic, historical, linguistic, national-cultural and other characteristics. Working with toponymic material serves as a means of stimulating interest in the study of the past and present of your region by searching for connections between the geographical conditions of the area, the language of the people and their reflection in geographical names, which are continuously associated with the natural features and historical past of the region, with the names of outstanding countrymen. Toponymic vocabulary accumulates the key stages of the development of material and spiritual culture, contributes to the preservation of the names of surrounding natural objects in memory, which generates love for the native land, develops ecological culture, arouses interest in research work. This article presents a productive version of the pedagogical technology that ensures the implementation of the ideas of the formation of toponymic literacy within the framework of the organization of project activities for the study of regional topoobjects in connection with their geographical, regional and linguistic-cultural characteristics. In the practice of the educational process, the described technology can be presented as a three-component option - a linguistic geographical passport, a linguistic portrait, a linguistic and cultural biography - allowing to explore topoobjects at different levels. The work with the presented models contributes to the integration of naturalgeographical and humanitarian directions in the development of toponymic literacy in education. One of the important conditions for the development of toponymic literacy is the reliance on the regionalization of the content of education, the inclusion of potential reflecting the national and cultural traditions of the region, the use of tools for linguistic study of topoobjects, the use of lexical-semantic, structural-grammatical and wordformation analysis of toponyms. Toponymic material requires a consistent and systematic introduction, the presence of linguistic commentary and reliance on familiar word-formation models. Cultural commentary contributes to the disclosure of the meanings of topoformants. Familiarity with toponymic material helps to increase students' interest in literature, folklore, in particular toponymic legends related to the origin of geographical names.

\section{REFERENCE LIST}

Gonchar E.A. (2014). Technology of formation of toponymic competence among future geography teachers. Siberian pedagogical journal. No. 3/ 2014. Pp. 93-98.

Gordova Yu.Yu. (2014). Toponym card in the information system "Toponymy of Russia". Philological sciences. Questions of theory and practice .Tambov. No. 12 (42). P. II. Pp. 58-61.

Ilyin D.Yu.(2018). Linguoecological portrait of a regional toponymicon: criteria for description. Bulletin of the Volgograd State University. Series 2, Linguistics. Vol. 17, No. 3. Pp. 99-107.

Khabibullina F. Ya., Ivanova I.G. (2020). Acentropinae geographical names of the Republic of Mari EI Republic of Tatar origin: toponymic zone. Finno-Ugric world. Vol. 12, No. 3. Pp. 259-285.

Khabibullina F. Ya., Ivanova I.G. (2020). Lexical-semantic classification of microtoponyms of the Republic of 
Proceedings of INTCESS 2022-9th International Conference on Education \& Education of Social Sciences 17-18 January 2022- Online Conference

Mari-El. Questions of Philology and translation studies: directions and perspectives of modern research. Cheboksary. Pp. 288-295.

Khabibullina F.Ya., Ivanova I.G., Trapeznikova G.A. (2018). The basic characteristics of aphorisms and means of their expression in the russian and french discourse. 5th International Conference on Education and Social Sciences (Intcess 2018). Pp. 543-555. 